INTERNATIONAL UNION OF THEORETICAL

AND APPLIED MECHANICS

\title{
IRREVERSIBLE ASPECTS OF CONTINUUM MECHANICS \\ AND \\ TRANSFER OF PHYSICAL CHARACTERISTICS IN MOVING FLUIDS
}

SYMPOSIA VIENNA, JUNE 22-28, 1966

EDITORS
H. PAR K US
VIENNA
L. I. SEDOV
Moscow

WITH 87 FIGURES

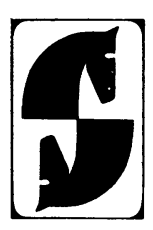

1968

SPRINGER-VERLAG

NEW YORK 
All rights reserved

No part of this book may be translated or reproduced in any form without written permission from Springer-Verlag

(C) 1968 by Springer -Verlag/Wien

Softcover reprint of the hardcover lst edition 1968

Library of Congress Catalog Card Number 68-11180

ISBN 978-3-7091-5583-7 ISBN 978-3-7091-5581-3 (eBook) DOI 10.1007/978-3-7091-5581-3 


\section{Preface}

At its meeting on April 23, 1965 in Paris the Bureau of IUTAM decided to have a Symposium on the Irreversible Aspects of Continaum Mechanics held in June 1966 in Vienna. In addition, a Symposium on the Transfer of Physical Characteristics in Moving Fluids which, originally, had been scheduled to take place in Stockholm was rescheduled to be held in Vienna immediately following the Symposium on the Irreversible Aspects of Continuum Mechanics. It was felt that the subjects of the two symposia were so closely related that participants should be given an opportunity to attend both.

Both decisions were unanimously approved by the members of the General Assembly of IUTAM. Prof. H. Parkus, Vienna, was appointed Chairman of the Symposium on the Irreversible Aspects, and Prof. L. I. Sedov, Moscow, was appointed Chairman of the Symposium on the Transfer of Physical Characteristics, with Prof. Parkus being responsible for the local organization of both symposia.

In accordance with the policy set forth by IUTAM, membership of the Symposia was limited and by invitation only. Financial support for covering the costs of organization and for a partial defrayal of the accomodation and traveling expenses of the participants was provided by IUTAM and by the Austrian Ministry of Education.

The Scientific Committee of the Symposium on the Irreversible Aspects of Continuum Mechanics consisted of the following members:

Prof. H. Parkus, Vienna, Chairman

Prof. S. R. DE GROot, Amsterdam

Prof. F. K. G. ODQvist, Stockholm

Prof. W. Olszak, Warsaw

Prof. W. Prager, Providence, R. I.

Prof. M. Roy, Paris

Prof. L. I. Sedov, Moscow

Prof. H. Ziegler, Zürich

(Prof. De Groot was unable to attend the Symposium

The primary purpose of the Symposium was to bring together leading scientists from the fields of Continuum Mechanics and Thermodynamics. Of these two fields which, in the past, have developed more or less inde 
pendently Continuum Mechanics has now reached a stage where further progress appears impossible without the inclusion of thermodynamic concepts. Emphasis was on the basic concepts in both fields, and not on applications. 23 papers were presented. Discussions were unusually lively and highly fruitful. Although unification of the two main schools of thought still seems to be a matter of the distant future, considerable progress has been made at the Symposium towards closing the gap.

The Scientific Committee of the Symposium on the Transfer of Physical Characteristics in Moving Fluids consisted of

Prof. L. I. Sedov, Moscow, Chairman

Prof. H. Parkus, Vienna, Vice-Chairman

Prof. S. B. Berndt, Stockholm

Prof. S. R. DE GROoT, Amsterdam

Prof. H. W. Liepmann, Pasadena

Prof. M. J. LighthiLL, London

Prof. M. Roy, Paris

A free and sapid discussion followed the presentation of the papers.

Vienna and Moscow, September 1967

H. Parkus, L. I. Sedov 


\section{Sessions}

Wednesday, June 22, 1966

Chairman: B. R. SETH

L. I. SEDov: Variational methods of constructing models of continuous media.

D. C. DRUCKER: On the continuum as an assemblage of homogeneous elements or states.

\section{Chairman: U. UHLHORN}

H. ZIEGLER: A possible generalization of Onsager's theory.

C. Truesdell: Thermodynamics for beginners.

\section{Chairman: P. M. NAGHDI}

B. D. Coleman ${ }^{1}$ : Thermodynamics and wave propagation in non-linear materials with memory.

W. OlszaK ${ }^{2}$ : On thermodynamics of the differential type material.

S. KALISKI: Čerenkov generation of thermal waves for the wave equations of thermoelectro-magneto-elasticity.

Thursday, June 23, 1966

Chairman: J. HuLT

E. T. Onat: The notion of state and its implications in thermodynamics of inelastic solids.

J. MeIXner: TIP has many faces.

\section{Chairman: G. A. KLuitenberG}

J. F. Besseling: A thermodynamic approach to rheology.

Chairman: A. M. Freudenthal

M. REINER: The influence of dissipated stresswork on the rupture of materials.

J. KESTIN : On the application of the principles of thermodynamics to strained solid materials.

R. S. RIVLIN ${ }^{3}$ : Generalized continuum mechanics.

\section{Friday, June 24, 1966}

Chairman: D. C. DRUCKeR

W. Prager: Composite stress-strain relations for elastoplastic solids.

E. H. LEE ${ }^{4}$ : Finite strain elastic-plastic theory.

1 Jointly with M. E. GurTin.

2 Jointly with P. Perzyna.

${ }^{3}$ Jointly with A. E. Green.

${ }^{4}$ Jointly with D. T. LIU. 


\section{Chairman: J. Kestin}

P. M. NAGHDI ${ }^{1}$ : A thermodynamic development of elastic-plastic continua.

G. S. ShapIRo: On conditions of yielding and fracture for viscoelastic-plastic bodies.

\section{Chairman: S. KALISKI}

A. M. FreudenthaL ${ }^{2}$ : Accumulation of second-order strain in workhardening media.

W. NowACKI: Couple-stresses in the theory of thermoelasticity.

G. HERRMANN ${ }^{3}$ : On stress waves in viscoelastic media conducting heat.

Saturday, June 25, 1966

Chairman: E. H. LEE

YU. N. RABotNov: Kinetics of creep and creep rupture.

U. UHLHORN : Thermomechanics of a continuous system with internal structure.

J. HULT: Phenomenological aspects of creep irreversibility.

Monday, June 27, 1966

Chairman: S. B. BERNDT

B. R. SETH: Irreversible transition in continuum mechanics.

YU. P. LUNKIN: Vibrational dissociation relaxation in a multicomponent mixture of viscous heat-conducting gases.

Chairman: N. FrössLING

V. N. Nikolaevskir: Transfer phenomena in fluid-saturated porous media.

Tuesday, June 28, 1966

Chairman: M. J. LIGHTHILL

F. N. FRENKIEL ${ }^{4}$ : Joint probability density distributions in a turbulent flow.

J. ZemáneK: Die Beeinflussung der Intensität des Transportprozesses durch das dynamische Verhalten der Phasengrenze Flüssigkeit-Gas oder FlüssigkeitDampf.

${ }^{1}$ Jointly with A. E. Green.

2 Jointly with MARIa RoNAY.

${ }^{3}$ Jointly with J. D. ACHenBaCh and S. M. Vogel.

4 Jointly with P. S. KLEBANOFF. 


\section{List of Participants}

Adомеiт, Dr. G., Rheinisch-Westfälische Technische Hochschule Aachen, Templergraben 55, D-51 Aachen, Germany.

Axelrad, Dr. D. R., Department of Mechanical Engineering, McGill University, Montreal 2, Canada.

Beckers, Dr. H. L., Koninklijke Shell-Laboratorium, Amsterdam-N, The Netherlands.

Bednarczyk, Dr. H., Technische Hochschule Wien, Karlsplatz 13, A-1040 Wien, Austria.

BĚLík, Docent Ing. L., CSc., Spojovací 5, Plzeň, Č.S.S.R.

Berndt, Prof. S. B., Kungliga Tekniska Högskolan, Stockholm 70, Sweden.

Besseling, Prof. J. F., Technische Hogeschool Delft, Mekelweg 2, Delft, The Netherlands.

Brun, Prof. L., Laboratoire de Mécanique des Solides, École Polytechnique, 17 Rue Descartes, Paris Ve, France.

Coleman, Prof. B. D., Mellon Institute, 4400 Fifth Avenue, Pittsburgh, Pa. 15213, U. S. A.

Devillez, Ing. C., École Polytechnique, Faculté des Sciences Appliquées, Université Libre de Bruxelles, Bruxelles, Belgium.

Drucker, Prof. D. C., Division of Engineering, Brown University, Providence, R. I. 02912, U.S. A.

Fenz, Edith, Technische Hochschule Wien, Karlsplatz 13, A-1040 Wien, Austria.

Frnzi, Prof. L., Istituto di Scienza delle Costruzioni della Facoltà di Architettura, Politecnico Milano, Milano, Italy.

Fiszdon, Prof. W., Polskiej Akademii Nauk, ul. Swiętokrzyska 21, Warszawa, Poland.

Frank, Dr. W., Bundesministerium für Bauten und Technik, Stubenring 1, A-1010 Wien, Austria.

Frenkiel, Prof. F. N., Applied Mathematics Laboratory, David Taylor Model Basin, Washington, D. C. 20007, U. S. A.

Freudenthal, Prof. A. M., Department of Civil Engineering and Engineering Mechanics, Columbia University, New York, N. Y. 10027, U. S. A.

Frössling, Prof. N., The Institute of Applied Thermo- and Fluid Dynamics, Chalmers University of Technology, Gibraltargatan 5 M, Gothenburg S, Sweden.

GrIolr, Prof. G., Seminario Matematico, Università di Padova, Padova, Italy.

Herrmann, Prof. G., The Technological Institute, Northwestern University, Evanston, Ill. 60201, U. S. A.

Herrnegger, F., Institut für Theoretische Physik, Universität Innsbruck, A-6020 Innsbruck, Austria. 
Hult, Prof. J., Division of Strength of Materials, Chalmers University of Technology, Gibraltargatan 5 M, Gothenburg S, Sweden.

Kaliski, Prof. S., Polskiej Akademii Nauk, ul. Swiętokrzyska 21, Warszawa, Poland.

Kestin, Prof. J., Division of Engineering, Brown University, Providence, R. I. 02912, U. S. A.

Kluitenberg, Dr. G. A., Technische Hogeschool te Eindhoven, Insulindelaan 2, Eindhoven, The Netherlands.

KoIter, Prof. W. T., Technische Hogeschool Delft, Mekelweg 2, Delft, The Netherlands.

Kröner, Prof. E., Institut für Theoretische Physik, Bergakademie Clausthal, D-3392 Clausthal-Zellerfeld, Germany.

LeE, Prof. E. H., Division of Engineering Mechanics, Stanford University, Stanford, Calif. 94305, U. S. A.

Lighthill, Prof. M. J., Imperial College of Science and Technology, University of London, South Kensington, London S. W. 7, England.

Lun'kin, Prof. Yu. P., c/o Prof. G. K. Mrkhailov, U. S. S. R. National Committee on Theoretical and Applied Mechanics, Leningrad Avenue 7, Moscow A-40, U.S.S. R.

MAIER, Prof. G., Istituto di Scienza delle Costruzioni della Facoltà di Architettura, Politecnico Milano, Milano, Italy.

MANDL, Dr. G., Volmerlaan 6, Rijswijk Z. H., The Netherlands.

Mazur, Prof. P., Instituut Lorentz, Steenschuur, Leiden, The Netherlands.

Meixner, Prof. J., Institut für Theoretische Physik, Rheinisch-Westfälische Technische Hochschule Aachen, Templergraben 55, D-51 Aachen, Germany.

MikhaIlov, Prof. G. K., U. S. S. R. National Committee on Theoretical and Applied Mechanics, Leningrad Avenue 7, Moscow A-40, U. S. S. R.

MülLER, Dr. I., Institut für Theoretische Physik, Rheinisch-Westfälische Technische Hochschule Aachen, Templergraben 55, D-51 Aachen, Germany.

Naghdi, Prof. P. M., Division of Applied Mechanics, Room 6141, Etcheverry Hall, University of California, Berkeley, Calif. 94720, U. S. A.

Nikolatvskir, Prof. V. N., Institute of Physics of the Earth, U. S. S. R. Academy of Sciences, Bol. Gruzinskaya 10, Moscow G-242, U. S. S. R.

Niondson, Prof. F. I., Department of Applied Mechanics, The Technical University of Denmark, Rigensgade 13, Copenhagen K, Denmark.

Nowacki, Prof. W., Polskiej Akademii Nauk, ul. Swiętokrzyska 21, Warszawa, Poland.

Odquist, Prof. F. K. G., The Royal Institute of Technology, Stockholm 70, Sweden. Olesiak, Prof. Z., ul. F. Joliot Curie 7 m. 24, Warszawa 87, Poland.

Olszak, Prof. W., Polskiej Akademii Nauk, ul. Swiętokrzyska 21, Warszawa, Poland.

Onat, Prof. E. T., Yale University, Winchester Hall, 15 Prospect Street, New Haven, Conn. 06520, U. S. A.

Parkus, Prof. H., Technische Hochschule Wien, Karlsplatz 13, A-1040 Wien, Austria.

Perzyna, Doz. Dr. P., Polskiej Akademii Nauk, ul. Swiętokrzyska 21, Warszawa, Poland.

PlochоскI, Doz. Dr. Z., Polskiej Akademii Nauk, ul. Swiętokrzyska 21, Warszawa, Poland. 
Prager, Prof. W., Department of the Aerospace and Mechanical Engineering Sciences, P. O. Box 109, University of California, La Jolla, Calif. 92037, U. S. A.

Přkvrátil, Ing. R., Department of Mechanics, Slovak Technical University, Tolstého 1, Bratislava, Č. S. S. R.

Raвotnov, Prof. Yu. N., Institute of Mathematics and Mechanics, Moscow State University, Moscow B-234, U. S. S. R.

Radenkovic, Prof. D., Laboratoire de Mécanique des Solides, École Polytechnique, 17 Rue Descartes, Paris Ve, France.

ReIner, Prof. M., Technion - Israel Institute of Technology, Haifa, Israel.

Rimrotт, Prof. F. P. J., Department of Mechanical Engineering, University of Toronto, Toronto 5, Canada.

Rivlin, Prof. R. S., Center for the Application of Mathematics, Lehigh University, Bethlehem, Pa. 18015, U. S. A.

Roy, Prof. M., 55 Boulevard Malesherbes, Paris VIIIe, France.

Save, Prof. M., Département de Mécanique, Faculté Polytechnique de Mons, Rue de Houdain, Mons, Belgium.

Savin, Prof. G. N., Institute of Mechanics, Academy of Sciences of the Ukrainian S. S. R., ul. Chkalora-55b, Kiev, U. S. S. R.

Schwarzl, Dr. F. R., Centraal Laboratorium t. n. o., Postbox 217, Delft, The Netherlands.

Sedov, Prof. L. I., U. S. S. R. National Committee on Theoretical and Applied Mechanics, Leningrad Avenue 7, Moscow A-40, U. S. S. R.

SETH, Prof. B. R., Dibrugarh University, Dibrugarh, Assam, India.

ShapIRo, Prof. G. S., Institute of Mechanics, U. S. S. R. Academy of Sciences, Leningrad Avenue 7, Moscow A-40, U. S. S. R.

TANI, Prof. I., Institute of Space and Aeronautical Science, University of Tokyo, Komaba, Meguro-ku, Tokyo, Japan.

Thomann, Dr. H., The Aeronautical Research Institute of Sweden (FFA), Bromma 11, Sweden. ·

TorRe, Dr. C., Bundesministerium für Landesverteidigung, A-1024 Wien, Austria.

Truesdell, Prof. C., The Johns Hopkins University, Baltimore, Md. 21218, U.S. A.

UhLHORN, Prof. U., Tekniska Högskolan i Lund, Lund, Sweden.

Zeman, Dr. J. L., Technische Hochschule Wien, Karlsplatz 13, A-1040 Wien, Austria.

ZemáNeK, Dipl. Ing. J., CSc., SVUSS Staatliches Forschungsinstitut für Maschinenbau, Běchovice-Prag, Č. S. S. R.

Ziegler, Dr. F., Technische Hochschule Wien, Karlsplatz 13, A-1040 Wien, Austria.

Ziegler, Prof. H., Eidgenössische Technische Hochschule, Zürich, Switzerland. 


\section{Contents}

Achenbach, J. D., S. M. Vogel and G. Herrmann : On Stress Waves in Viscoelastic Media Conducting Heat . . . . . . . . . . . . . . . . . . 1

Besseling, J. F.: A Thermodynamic Approach to Rheology (With 1 Figure) 16

Coleman, B. D., and M. E. Gurtin: Thermodynamics and Wave Propagation in Non-Linear Materials with Memory . . . . . . . . . . . . . . . 54

Drucker, D. C.: On the Continuum as an Assemblage of Homogeneous Elements or States (With 9 Figures) . . . . . . . . . . . . . . . . . . 77

Frenkier, F. N., and P. S. Klebanoff: Joint Probability Density Distributions in a Turbulent Flow . . . . . . . . . . . . . . . . . . . . . 94

Freudenthal, A. M., and Maria Ronay : Accumulation of Second-Order Strain in Workhardening Media (With 24 Figures) . . . . . . . . . . . . . . 97

Green, A. E., and P. M. NAGHDI: A Thermodynamic Development of ElasticPlastic Continua. . . . . . . . . . . . . . . . . . . . . . . 117

Green, A. E., and R. S. Rrvlin: Generalized Continuum Mechanics . . . . 132

HuLt, J.: Phenomenological Aspects of Creep Irreversibility (With 10 Figures) 146

KaLISKr, S.: Čerenkov Generation of Thermal Waves for the Wave Equations of Thermo-Electro-Magneto-Elasticity . . . . . . . . . . . . . . . 159

Knstin, J.: On the Application of the Principles of Thermodynamics to Strained Solid Materials (With 15 Figures) . . . . . . . . . . . . . . . . 177

Lee, E. H., and D. T. Lru: Finite Strain Elastic-Plastic Theory (With 2 Figures). . . . . . . . . . . . . . . . . . . . . . . . . . . 213

LrghтншL, M. J. : Application of Variational Methods in the Non-Linear Theory of Dispersive Wave Propagation . . . . . . . . . . . . . . . . . 223

LUNkIN, YU. P.: Vibrational Dissociation Relaxation in a Multicomponent Mixture of Viscous Heat-Conducting Gases (With 6 Figures) . . . . . . 229

MeIxner, J.: TIP Has Many Faces . . . . . . . . . . . . . . . . . . . 237

NrkolakvskiI, V. N.: Transfer Phenomena in Fluid-Saturated Porous Media 250

Nowackr, W.: Couple-Stresses in the Theory of Thermoelasticity . . . . . . 259

Orszak, W., and P. Perzyna: On Thermodynamics of the Differential Type Material . . . . . . . . . . . . . . . . . . . . . . . . . . 279

ONat, E. T.: The Notion of State and Its Implications in Thermodynamics of Inelastic Solids . . . . . . . . . . . . . . . . . . . . . . . . . 292

Prager, W.: Composite Stress-Strain Relations for Elastoplastic Solids (With 6 Figures) . . . . . . . . . . . . . . . . . . . . . . . 315

Rabotnov, YU. N.: Kinetics of Creep and Creep Rupture . . . . . . . . . 326

REINER, M.: The Influence of Dissipated Stresswork on the Rupture of Materials (With 3 Figures) . . . . . . . . . . . . . . . . . . . . . 335 
Sedov, L. I.: Variational Methods of Constructing Models of Continuous Media 346

Seth, B. R.: Irreversible Transition in Continuum Mechanics . . . . . . . 359

SHAPIRo, G. S.: On Conditions of Yielding and Fracture for Viscoelastic-Plastic

Bodies . . . . . . . . . . . . . . . . . . 367

Truesdell, C.: Thermodynamics for Beginners . . . . . . . . . . . 373

UHLноR,, U.: Thermomechanics of a Continuous System with Internal Structure . . . . . . . . . . . . . . . . . . . . . . . . . . 390

ZemáNEK, J.: Die Beeinflussung der Intensität des Transportprozesses durch das dynamische Verhalten der Phasengrenze Flüssigkeit-Gas oder Flüssigkeit-Dampf (Mit 6 Abbildungen) . . . . . . . . . . . . . . . . . . . 394

Ziegler, H.: A Possible Generalization of Onsager's Theory (With 5 Figures) 411 